\title{
Exploring characteristics that prevent the derailment of women leaders
}

\author{
Michelle Nobre \\ Jos Coetzee \\ Marietjie van der Walt \\ Wilfred I. Ukpere
}

\author{
Department of Industrial Psychology and People Management, \\ Faculty of Management, University of Johannesburg, South Africa \\ Corresponding author: wiukpere@uj.ac.za
}

Doi:105901/mjss.2014.v5n2p729

\begin{abstract}
The number of women in senior leadership positions globally remains inequitable with recent statistics showing that female directors make up a mere $16 \%$ of company boards across the European Union, $20 \%$ of senior executives in U.S. companies, and $19.1 \%$ of top and $28.2 \%$ of senior managers in South African companies. This article provides greater understanding of why some women succeed in these positions whilst others have their careers derail. Whilst taking cognisance of exiting research on leadership derailment, this article explores the personal construct systems of leaders who have avoided or overcome derailment. This aims to facilitate a greater appreciation of the role of intrinsic characteristics of women leaders, thereby creating a more integrated and holistic understanding of leadership derailment. This article further aims to extend the traditional definition of leadership derailment to include the experiences of women leaders who have avoided or overcome derailment.
\end{abstract}

Keywords: derailment, women leaders, personal construct theory, personal construct, core construct, personal construct system.

\section{Introduction}

In the context of the global leadership crisis and more specifically, the scarcity of women in senior and executive leadership positions, leadership derailment amongst women remains topical. Several studies espouse the benefits of better representation of women leaders in business, which include, amongst others, higher return on equity, superior sales, and higher return on investment. Despite this, the on-going challenges faced by women leaders in the workplace, remains problematic. Research over time highlights the challenges of women leaders such as gender stereotyping, prejudice and discrimination, organisational practices and culture, the "glass ceiling" phenomenon and more recently the "glass cliff" phenomenon.

Whist these challenges cannot be denied, neither can the fact that some women are able to succeed despite the barriers which they face. Derailment research has typically focused on the characteristics of leaders who have derailed, whilst little, if any research, has focused on the characteristics of those who have overcome derailment. This article explores specifically the characteristics of women leaders who have either avoided or overcome derailment. Research findings in this article are framed within the broad ambit of personal construct theory and are presented in the form of a framework of characteristics which prevent derailment.

\section{Research objective}

The main objective of this article is to explore the characteristics that prevent the derailment of women leaders and to present an integrated framework of these characteristics. A secondary aim of this article is to present a more inclusive definition of leadership derailment as it is experienced and interpreted by women executive leaders.

\section{Literature Review: Leadership derailment}

Leadership derailment is defined as being when an executive who is placed in an executive role in an organization and was judged to have the ability to be successful in this executive role, is fired, asked to resign, is forced out of the organization, demoted, or has their career plateau unexpectedly (Schmidt, 2009; Lombardo \& McCauley, 1988). 
Populist commentary on leadership derailment (Furnham, 2010) lists the following types of bad leaders: aberrant leaders; anti-social leaders; dark-side (triad) leaders; derailed leaders; despotic leaders, destructive leaders, incompetent leaders, malignant leaders, toxic leaders and tyrannical leaders and:

"...emphasizes the idea of being thrown off course. Trains on tracks derail. Leaders set fair in a particular direction deviate from the path, unable to move forward. It is sometimes hyphenated with the next word in the dictionary, namely deranged, which implies not only a breakdown in performance, but also insanity" (Furnham, 2010, p. 6).

Hogan and Hogan (2001) postulate that derailment is due to "dark side" personality traits, which are linked to personality disorders described in the Diagnostic and Statistical Manual of Mental Disorders - Four (DSM IV), whilst Kellerman (2004) describes seven types of bad leadership which include rigid, incompetent, callous, intemperate, insular, corrupt, and evil.

The study of leadership derailment began in the 1960's with the most prominent thought leaders over time being Bentz (1967, 1985 a, 1985 b, 1990), McCall and Lombardo (1983), Morrison, White and Van Velsor (1987) Lombardo, Ruderman and McCauley( 1988), McCauley and Lombardo (1990), Van Velsor and Leslie (1995), Hogan and Hogan ( 2001), Eichinger and Lombardo (2003), Dotlich and Cairo (2003), Finkelstein (2003) and Rasch, Shen, Davies and Bono ( 2008). An integrated summary and comparison of the factors, personality characteristics and behaviours, which thought leaders over time have linked to derailment, are outlined in Table 1 below:

Table 1: Characteristics associated with leadership derailment

\begin{tabular}{|c|c|c|c|c|c|c|c|c|}
\hline $\begin{array}{l}\text { Bentz } \\
\text { (1985 a) }\end{array}$ & $\begin{array}{l}\text { Hogan and } \\
\text { Hogan } \\
(2001)\end{array}$ & $\begin{array}{l}\text { Eichinger \& } \\
\text { Lombardo } \\
(2003)\end{array}$ & $\begin{array}{l}\text { McCall and } \\
\text { Lombardo } \\
\text { (1983) }\end{array}$ & $\begin{array}{l}\text { Lombardo } \\
\text { et al (1988) }\end{array}$ & $\begin{array}{l}\text { McCauley \& } \\
\text { Lombardo } \\
\text { (1990) }\end{array}$ & $\begin{array}{l}\text { Dotlich \& Cairo } \\
(2003)\end{array}$ & $\begin{array}{l}\text { Finkelstein } \\
(2003)\end{array}$ & $\begin{array}{l}\text { Rasch, Shen, } \\
\text { Davies \& Bono } \\
(2008)\end{array}$ \\
\hline \multicolumn{3}{|c|}{ Personality traits leading to derailment } & \multicolumn{6}{|c|}{ Behaviours leading to derailment } \\
\hline $\begin{array}{l}\text { Lacked } \\
\text { business } \\
\text { skills }\end{array}$ & Excitable & $\begin{array}{l}\text { Poor } \\
\text { administrativ } \\
\text { e skills }\end{array}$ & $\begin{array}{l}\text { Experience } \\
\text { d specific } \\
\text { business } \\
\text { problems }\end{array}$ & $\begin{array}{l}\text { Inability to } \\
\text { build a } \\
\text { cohesive } \\
\text { team }\end{array}$ & \begin{tabular}{|l} 
Problems \\
with \\
interpersonal \\
relationships
\end{tabular} & Arrogance & $\begin{array}{l}\text { Overestimate } \\
\text { their strength } \\
\text { and } \\
\text { underestimate } \\
\text { the strength of } \\
\text { their } \\
\text { competition }\end{array}$ & $\begin{array}{l}\text { Avoiding } \\
\text { conflict and } \\
\text { people } \\
\text { problems }\end{array}$ \\
\hline $\begin{array}{l}\text { Unable to } \\
\text { deal with } \\
\text { complexity }\end{array}$ & Skeptical & $\begin{array}{l}\text { Difficulty } \\
\text { making tough } \\
\text { choices }\end{array}$ & Insensitive & $\begin{array}{l}\text { Over and } \\
\text { under } \\
\text { managing }\end{array}$ & $\begin{array}{l}\text { Difficulty } \\
\text { moulding } \\
\text { staff }\end{array}$ & Melodrama & $\begin{array}{l}\text { Put personal } \\
\text { interests } \\
\text { ahead of } \\
\text { company } \\
\text { interests }\end{array}$ & $\begin{array}{l}\text { Poor emotional } \\
\text { control }\end{array}$ \\
\hline $\begin{array}{l}\text { Reactive } \\
\text { and } \\
\text { operational }\end{array}$ & Cautious & $\begin{array}{l}\text { Lack of } \\
\text { strategic } \\
\text { thinking }\end{array}$ & $\begin{array}{l}\text { Cold, } \\
\text { arrogant } \\
\text { and aloof }\end{array}$ & $\begin{array}{l}\text { Overly } \\
\text { ambitious }\end{array}$ & $\begin{array}{l}\text { Difficulty in } \\
\text { making } \\
\text { strategic } \\
\text { transitions }\end{array}$ & Volatility & $\begin{array}{l}\text { Arrogant and } \\
\text { make reckless } \\
\text { decisions }\end{array}$ & Over controlling \\
\hline $\begin{array}{l}\text { Unable to } \\
\text { delegate }\end{array}$ & Reserved & $\begin{array}{l}\text { Failure to } \\
\text { build a team }\end{array}$ & $\begin{array}{l}\text { Betrayed } \\
\text { trust }\end{array}$ & $\begin{array}{l}\text { Not supportive } \\
\text { and demanding } \\
\text { of subordinates }\end{array}$ & $\begin{array}{l}\text { Lack of } \\
\text { follow } \\
\text { through }\end{array}$ & $\begin{array}{l}\text { Excessive } \\
\text { caution }\end{array}$ & $\begin{array}{l}\text { Eliminate } \\
\text { anyone who } \\
\text { might } \\
\text { challenge } \\
\text { their decisions }\end{array}$ & $\begin{array}{l}\text { Poor task } \\
\text { performance }\end{array}$ \\
\hline $\begin{array}{l}\text { Unable to } \\
\text { build a } \\
\text { team }\end{array}$ & Leisurely & $\begin{array}{l}\text { Lack of } \\
\text { interpersonal } \\
\text { savvy }\end{array}$ & $\begin{array}{l}\text { Over } \\
\text { managed } \\
\text { and did not } \\
\text { delegate } \\
\text { enough }\end{array}$ & $\begin{array}{l}\text { Overtly } \\
\text { emotional }\end{array}$ & $\begin{array}{l}\text { Over- } \\
\text { dependence }\end{array}$ & Habitual distrust & $\begin{array}{l}\text { Ignore } \\
\text { operations } \\
\text { while trying to } \\
\text { manage their } \\
\text { company's } \\
\text { image }\end{array}$ & $\begin{array}{l}\text { Poor planning, } \\
\text { organisation } \\
\text { and/or } \\
\text { communication }\end{array}$ \\
\hline $\begin{array}{l}\text { Unable to } \\
\text { build } \\
\text { relationshi } \\
\text { ps with a } \\
\text { network of } \\
\text { contacts }\end{array}$ & Arrogant & $\begin{array}{l}\text { Poor political } \\
\text { skills }\end{array}$ & $\begin{array}{l}\text { Overly } \\
\text { ambitious }\end{array}$ & $\begin{array}{l}\text { Insensitive, } \\
\text { cold and } \\
\text { arrogant }\end{array}$ & \begin{tabular}{|l|} 
Strategic \\
differences with \\
management
\end{tabular} & Aloofness & $\begin{array}{l}\text { Minimize } \\
\text { difficult } \\
\text { obstacles and } \\
\text { don't plan } \\
\text { accordingly }\end{array}$ & $\begin{array}{l}\text { Rumour } \\
\text { mongering and } \\
\text { inappropriate } \\
\text { use of } \\
\text { information }\end{array}$ \\
\hline $\begin{array}{l}\text { Emotions } \\
\text { cloud their } \\
\text { judgment }\end{array}$ & Mischievous & $\begin{array}{l}\text { Inability to } \\
\text { deal with } \\
\text { conflict }\end{array}$ & $\begin{array}{l}\text { Failed to } \\
\text { staff } \\
\text { effectively }\end{array}$ & $\begin{array}{l}\text { Maintaining } \\
\text { poor relations } \\
\text { with staff }\end{array}$ & & Mischievousness & $\begin{array}{l}\text { Rely on } \\
\text { outdated } \\
\text { strategies and } \\
\text { tactics }\end{array}$ & Procrastination \\
\hline $\begin{array}{l}\text { Slow to } \\
\text { learn }\end{array}$ & Colourful & $\begin{array}{l}\text { Questionable } \\
\text { integrity }\end{array}$ & $\begin{array}{l}\text { Unable to } \\
\text { think } \\
\text { strategically }\end{array}$ & $\begin{array}{l}\text { Overriding } \\
\text { personality } \\
\text { defects }\end{array}$ & & Eccentricity, & & $\begin{array}{l}\text { Failure to } \\
\text { consider } \\
\text { human needs }\end{array}$ \\
\hline \multirow[t]{4}{*}{$\begin{array}{l}\text { Seen to } \\
\text { have an } \\
\text { overriding } \\
\text { personality } \\
\text { defect }\end{array}$} & Imaginative & $\begin{array}{r}\text { Low self- } \\
\text { awareness }\end{array}$ & $\begin{array}{l}\text { Unable to } \\
\text { adapt to a } \\
\text { boss with a } \\
\text { different } \\
\text { style }\end{array}$ & & & $\begin{array}{l}\text { Passive } \\
\text { resistance }\end{array}$ & & $\begin{array}{l}\text { Failure to } \\
\text { manage and } \\
\text { nurture talent }\end{array}$ \\
\hline & Diligent & & \multirow{2}{*}{$\begin{array}{l}\text { Overly } \\
\text { dependent } \\
\text { on } \\
\text { advocate or } \\
\text { mentor. }\end{array}$} & & & perfectionism & & \\
\hline & & & & & & & & \\
\hline & Dutiful & & & & & $\begin{array}{l}\text { Eagerness to } \\
\text { please }\end{array}$ & & \\
\hline
\end{tabular}


In addition to the above, researchers have found that there are specific barriers and potential derailers which are unique to women executives (Schein, 1973; Schein, 1975; Eagly \& Johnson, 1990; Fiske, Bersoff, Borgida, Deaux \& Heilman, 1991; Eagly, Makhijani \& Klonsky, 1992; Morrison, 1992; Schein \& Mueller, 1992; Valian, 2000; Meyerson \& Fletcher, 2000; Powell, Butterfield, \& Parent, 2002; Powell \& Graves, 2003; Schneider, 2004; Heilman, Wallen, Fuchs \& Tamkins, 2004; Catalyst, 2005; Eisenhart, 2006; Schein, 2007; Schmidt, 2009). This research appears to overlap somewhat with similar factors emerging. The available literature on the internal as well as external factors leading to the derailment of women executives is thus summarised in table 2 below:

Table 2: Factors associated with leadership derailment amongst women executives

\begin{tabular}{|l|l|}
\hline $\begin{array}{l}\text { EXTERNAL FACTORS - Factors outside of women } \\
\text { leading to derailment }\end{array}$ & $\begin{array}{l}\text { INTERNAL FACTORS - Personality traits and behaviours } \\
\text { leading to derailment }\end{array}$ \\
\hline Gender Stereotyping & Leadership styles and behaviour \\
\hline Gendered organisations & The inability to adapt \\
\hline Gendered occupations & Wanting too much for oneself or other women \\
\hline Sex segregation & Not meeting performance expectations \\
\hline Tokenism & Problems with interpersonal relationships and networks \\
\hline Prejudice & Failure to meet business objectives \\
\hline The "glass ceiling" phenomenon & Inability to build and lead a team \\
\hline The "Glass cliff" phenomenon & Inability to learn from mistakes \\
\hline Organisational Culture & Not getting work out \\
\hline Business operations resulted in company eliminating jobs & Not managing strategy \\
\hline Discrimination & Relationship with the boss \\
\hline Sabotage & Education and development \\
\hline Organisational practices & Lack of initiative \\
\hline Other people's reactions to a competent women & Lack of accountability \\
\hline New senior leadership (not the boss) & \\
\hline
\end{tabular}

When considering the above research on leadership derailment in general as well as leadership derailment amongst women leaders, it is important to note that leadership derailment is a key strategic issue for organisations as leadership effectiveness is strongly correlated to organizational success factors such as retaining talent, customer satisfaction, employee engagement, and profitability. A better understanding of why some women succeed whilst others have their careers derail, is thus of great significance and could be traced from the personal construct theory.

\section{Personal construct theory}

This article explores the characteristics that prevent the derailment of women leaders within the context of personal construct theory. According to Kelly, who developed personal construct theory, "a person's processes are psychologically channelized by the ways in which he anticipates events" (Kelly, 1955, 46). Simply put, personal construct theory is primarily a theory of examining how humans continually construct meaning in a continually changing world (Epting \& Paris, 2006). We give meaning to our world and experiences by creating an unspoken theoretical framework, referred to as a personal construct system. It is within this system that we anticipate the future and engage with our environment.

An individual's personal construct system is made up of personal constructs and core constructs. Personal constructs allow us to make predictions about the future, as it is through our constructions of reality that we make sense of the world and anticipate events within it. Core constructs, which are higher order constructs, lie fundamentally at the heart of our sense of self, guiding each anticipatory choice, action and stance we take (Butler, 2006, p. 27). Core Constructs remain stable over time, leading us to preserve a core belief about ourselves, even in the face of invalidating evidence (Rowe, 2003).

For the fact that personal construct systems lie at a very low level of awareness, they are difficult to analyse and even more difficult to change. Core constructs are particularly difficult to identify and analyse (Leitner \& Thomas, 2003; McWilliams, 2004), and are difficult to change, even if they do not serve us well, and lead to derailment. 
Alternative constructions may be ..."avoided in our everyday thought processes because of the incompatibility with the rest of our life" (Epting \& Paris, 2006, p. 26). We attempt to preserve the core beliefs we have about ourselves, rather than seeking an alternative construction of the self. Thus invalidation of core constructs (belief about one's self) represents a profound threat for an individual. Experiences which fail to validate the self, lead to emotions such as sadness, guilt, and other negative emotions (Butler, 2006; McCoy, 1977).

This article explores the personal construct systems of women leaders who have not derailed with a view to contributing to our understanding of leadership derailment and empowering other women leaders by presenting alternative constructions, which may contribute to the prevention of their derailment.

\section{Research design and methodology}

For the purposes of this article, a qualitative research approach was adopted, making use of grounded theory. Whilst definitions of qualitative research and data may vary, (Lofland \& Lofland, 1984; Gilmore \& Carson, 1996; Bogdan, \& Biklen, 1998; Creswell, 1998; Mason, 1996; Strauss \& Corbin, 1990; Amaratunga, Baldry, Sarshar \& Newton, 2001; Schwandt, 2007; Denzin \& Lincoln, 2008), they share the following key features.

- It focuses on naturally occurring, ordinary events in natural settings, and creates a view of what real life is like.

- It has richness and is conducted within a framework of holism, with strong potential for revealing complexities. According to Amaratunga et al. (2001) such data provides rich, vivid descriptions, nested in a real life context.

- The fact that qualitative data is typically collected over a sustained period makes it powerful for studying any process.

- The inherent flexibility of qualitative studies gives further confidence that what has been going on is really understood.

- It is the best strategy for discovery, exploring a new area and developing hypotheses.

- It allows the researcher to become familiar with the area(s) of interest, to explore the field and consider the dimensions involved.

- The adaptability of qualitative methods allows for a reasonably flexible plan of action that may evolve with the researcher's experiential learning and development.

As per Schram (2006), the objective of grounded theory is the development of theory that is grounded in data. It focuses on generating theory based on the study of social situations. Schwandt (2007, p. 131) describes grounded theory is a "specific, highly developed, rigorous set of procedures for producing formal substantive theory of social phenomenon".

Based on the qualities and descriptions above, it was felt that a qualitative research approach making use of grounded theory was particularly suitable for the purposes of this research.

Purposeful and snowball sampling yielded five research participants who hold senior leadership positions across a wide spectrum of South African businesses. Extended in-depth interviews were conducted, digitally recorded and subsequently transcribed. Emerging categories and themes from the interviews, in conjunction with data from my personal diary and project journal as well as memos and field notes, were integrated to arrive at final interpretations and overall findings and results.

\section{Data analysis}

During the data analysis phase of the research, the following qualitative data analysis process within the grounded theory framework was carried out:

\section{Table 3: Data analysis process}

Data Analysis process followed in current study

Firstly getting an idea of the whole by reading all the transcripts and jotting down ideas.

Proceeding to each transcription and understanding the broad meaning it conveys and the main categories and topics which emerge.

Applying the main categories back to the data to establish whether new categories and codes emerged. 
Grouping the categories together to provide an alphabetical list of categories.

Appling line by line analysis to data in each transcription and code the data line-by-line.

Comparing and integrating the emerging categories to the categories already found from the previous analysis.

Conducting incident coding to compare the incidents with each other, and add emerging categories to the already established categories.

Applying theoretical coding to the established categories as a basis for the development of a theoretical framework.

As a point of departure to begin exploring the participants' definitions of derailment and the constructs which prevented them from derailing, we explored the participants' derailment stories and descriptions of their derailment experiences during the in-depth interviewing process. The participants' experiences of derailment are outlined in Table 4 below.

Table 4: Derailment experiences

\section{Construct}

Participant 1

Participants 1 described the situation where a project team was put together to deal with a specific project which was a few years in duration. She was the most senior person on the project team and when the project was complete, the rest of the team was absorbed back into the normal organisational structure.

Because of her seniority, for her, there was no position available. She was told that the organisation could "create" a position for her, which would encompass ad-hoc duties to assist the CEO. She experienced this as very difficult and as if she was being sidelined. She seriously considered leaving the organisation and had to struggle immensely with herself.

Eventually she opted to fill a position at a lower job grade and for two years reported to someone who had previously reported to her.

Participant 2

This participant reported the challenge of being appointed in the organisation due to employment equity requirements of the business, which placed pressure for the appointment of a woman.

In addition to this, she reported that the view of the organisation was that her role as General Manager: Human Resources, is traditionally a woman's role. She reported that both these factors present a number challenges that she continuously has to deal with.

She stated experiencing that she continually has to prove herself, even after years in the position. She believes that if she did not have the personality and approach that she does, this could easily have derailed her career.

Participant 3

This participant's challenge was not imposed on her by an external situation but rather by herself. P3 had to overcome aspects of her own personality which she believes would have led to her derailment.

\section{Participant 4}

She described failing her actuarial exams a number of times, whilst being employed in her current organisation, as almost derailing her career in the financial sector.

This had consequences for her career progression and the perception of decision makers of her.

\section{Participant 5}

P5 described reporting to a CEO whom she experienced as difficult and unreasonable in terms of the demands which he placed on her and in terms of his own personality and behavioural style.

She believes that her career would have been derailed had he not been forced to resign from the company.

Based on their experiences, the participants shared their personal definitions of derailment. These definitions are briefly outlined in table 5 below: 
Table 5: Derailment definitions

\begin{tabular}{|l|}
\hline Definition \\
\hline Participant 1 \\
\hline $\begin{array}{l}\text { When, due to discrimination, a women's success is undermined as a result of being forced to play a specific role in order to } \\
\text { be recognised as an equal }\end{array}$ \\
\hline Participant 2 \\
\hline Women blaming discrimination for not meeting career expectations \\
\hline Participant 3 \\
\hline Women who make excuses for their own lack of success \\
\hline Participant 4 \\
\hline Self-stereotyping and believing that women are less successful \\
\hline Participant 5 \\
\hline Not meeting the expectations that you set for yourself \\
\hline
\end{tabular}

After an exploration of the participants' derailment experiences and definitions, we undertook a deeper exploration of the underlying and pervasive constructions held by the participants that helped them to overcome or prevent their ultimate derailment. The results of participants' constructions of derailment are outlined in table 6 below:

Table 6: Constructs preventing derailment

\begin{tabular}{|c|c|c|}
\hline No & Construct & Description \\
\hline \multicolumn{3}{|c|}{ Participant 1} \\
\hline 1 & Self-confidence & $\begin{array}{l}\text { This participant described an overarching sense of self confidence and the self-assurance to } \\
\text { assert her needs. }\end{array}$ \\
\hline 2 & Positivity & She described her positive outlook on life. \\
\hline 3 & Emotional awareness & $\begin{array}{l}\text { P1 discussed elements such as managing own emotional impulses as well as the emotions of } \\
\text { others, emotional maturity and discerning between valid \& invalid criticism. }\end{array}$ \\
\hline 4 & Team work & The participant shared how she goes about leading her team. \\
\hline 5 & Relationship focus & The benefits to be gained from supporting colleagues and building relationships. \\
\hline 6 & $\begin{array}{l}\text { Resilience and coping } \\
\text { mechanisms }\end{array}$ & $\begin{array}{l}\text { P1 described her ability to cope in a crises as well as her ability to recover quickly from } \\
\text { setbacks. }\end{array}$ \\
\hline 7 & Work-life balance & $\begin{array}{l}\text { She described the importance of work-life balance and also being able to cope with the } \\
\text { conflict that different roles engender. }\end{array}$ \\
\hline 8 & $\begin{array}{l}\text { Responsiveness to own and } \\
\text { other's behaviours }\end{array}$ & $\begin{array}{l}\text { The participant described the importance of being alert to the emotional cues and responses } \\
\text { from others and adjusting her behaviour accordingly, especially in difficult situations or } \\
\text { where tough issues need to be confronted. }\end{array}$ \\
\hline 9 & Passion and drive & $\begin{array}{l}\text { Participant } 1 \text { saw herself as having a strong passion, drive and having a strong desire to } \\
\text { grow, lean, achieve, seek new challenges and self-actualize. }\end{array}$ \\
\hline 10 & $\begin{array}{l}\text { Recognition for and } \\
\text { Reinforcement from others } \\
\text { for contributions }\end{array}$ & $\begin{array}{l}\text { P1 shared the need to contribute and be recognised and receive reinforcement for one's } \\
\text { contributions. She shared how she experienced this as a child and how this has carried } \\
\text { through in her career. }\end{array}$ \\
\hline 11 & $\begin{array}{l}\text { Risk taking and following } \\
\text { one's instincts }\end{array}$ & She reported that risk taking behaviour has been beneficial to her. \\
\hline 12 & $\begin{array}{l}\text { Understanding and } \\
\text { capitalising gendered } \\
\text { behaviour }\end{array}$ & $\begin{array}{l}\text { P1 described how she deals with some of the gender issues that arise between her and her } \\
\text { male colleagues. She appears to frame the behaviour of her male colleagues in a specific } \\
\text { manner and to use it to her advantage. }\end{array}$ \\
\hline
\end{tabular}




\begin{tabular}{|c|c|c|}
\hline No & Construct & Supporting quotes \\
\hline \multicolumn{3}{|c|}{ Participant 2} \\
\hline 1 & "I'm okay" & $\begin{array}{l}\text { This participant described the importance of "being okay" with oneself, which in turn leads to } \\
\text { the ability to deal with criticism and assert oneself. } \\
\text { She described in some detail the importance of possessing a deeper seated lingrained } \\
\text { sense of self-belief. }\end{array}$ \\
\hline 2 & Positive thinking & $\begin{array}{l}\text { She shared her tactic of mentally refocusing from negative thoughts to positive thoughts, and } \\
\text { thinking about past successes in order to remain positive. }\end{array}$ \\
\hline 3 & $\begin{array}{l}\text { Emotional control and } \\
\text { self-awareness }\end{array}$ & $\begin{array}{l}\text { P2 shared the importance of maintaining emotional composure and the harm that women } \\
\text { do to their reputations and relationships by becoming over-emotional, "making a scene" } \\
\text { and coming across as irrational. }\end{array}$ \\
\hline 4 & $\begin{array}{l}\text { Nurturing relationships and } \\
\text { the needs of others }\end{array}$ & $\begin{array}{l}\text { The main areas which came through on this construct were 1) having a support structure; 2) } \\
\text { creating time to build relationships and socialize with colleagues; 3) focusing on the needs of } \\
\text { others and helping them achieve their goals. } \\
\text { An element of selflessness and putting others first also came through. In this interview a } \\
\text { strong sense of nurturing of others came through. }\end{array}$ \\
\hline 5 & $\begin{array}{l}\text { Stress management and } \\
\text { dealing with adversity }\end{array}$ & $\begin{array}{l}\text { The participant described being able to identify women who are perpetually stressed and } \\
\text { not coping with what is required of them. She went on to described how these women are } \\
\text { perceived negatively by the organisation and not entrusted to deal with gruelling or difficult } \\
\text { assignments. }\end{array}$ \\
\hline 6 & $\begin{array}{l}\text { Managing demands of } \\
\text { multiple roles }\end{array}$ & $\begin{array}{l}\text { She is a mother of two young children and described the on-going challenges that this } \\
\text { brings, particularly from a practical perspective when required to travel for business which } \\
\text { she does quite extensively. }\end{array}$ \\
\hline 7 & $\begin{array}{l}\text { Understanding behaviour } \\
\text { and dealing with conflict }\end{array}$ & $\begin{array}{l}\text { P2 spoke of protecting the self-esteem of colleagues and being sensitive to the consequences } \\
\text { of injuring the pride of others. } \\
\text { The Participant also described the importance of having insight into one's own emotional } \\
\text { triggers and the perceptions that one creates through one's behaviour. }\end{array}$ \\
\hline 8 & Success driven & $\begin{array}{l}\text { Participant } 2 \text { was unashamed and transparent in describing her desire for success and } \\
\text { doing what is required to achieve success. I reflected this back to P2, who then stated that } \\
\text { women feel that they cannot say out loud that they wanted to be successful, which impacts } \\
\text { on their ability to be so. }\end{array}$ \\
\hline 9 & $\begin{array}{l}\text { Accepting and giving } \\
\text { recognition for } \\
\text { achievements }\end{array}$ & $\begin{array}{l}\text { The participant spoke about the positive impact of the recognition for her accomplishments } \\
\text { which she received from her parents as a child, had on her, and how the recognition from } \\
\text { significant others today continues to help her succeed. }\end{array}$ \\
\hline 10 & Confidence to take risks & $\begin{array}{l}\text { She shared her perception that the women who derail are those who are reactive and fear } \\
\text { taking risks. She shared that one has to trust one's judgement when making decisions for } \\
\text { which the outcome is not always clear. }\end{array}$ \\
\hline 11 & $\begin{array}{l}\text { Identity as a women as part } \\
\text { of leadership identity }\end{array}$ & $\begin{array}{l}\text { P2 expressed the view that her role as a woman is integral to her role as a leader and, as } \\
\text { the only women on the executive team, very much forms part of her identity as a leader. }\end{array}$ \\
\hline 12 & $\begin{array}{l}\text { Dealing with gender } \\
\text { inequality }\end{array}$ & $\begin{array}{l}\text { She was quite open about the fact that sometimes being a woman leader is difficult. However } \\
\text { her approach is not to dwell on this and take issue with it, but rather accept the reality, and to } \\
\text { do what is required to succeed in the environment she finds herself in. This participant } \\
\text { expressed distaste for women who take unnecessary issue with gender }\end{array}$ \\
\hline
\end{tabular}

\begin{tabular}{|c|c|c|}
\hline No & Construct & Supporting quotes \\
\hline \multicolumn{3}{|c|}{ Participant 3} \\
\hline 1 & $\begin{array}{l}\text { Confidence in abilities and } \\
\text { ability to assert self }\end{array}$ & $\begin{array}{l}\text { The participant shared her sense of confidence in herself and her consequent confidence in } \\
\text { her opinions and the right to have her needs met. }\end{array}$ \\
\hline 2 & $\begin{array}{l}\text { Positive and calm } \\
\text { approach }\end{array}$ & $\begin{array}{l}\text { She discussed her ability to have a positive and calming influence on others, which she } \\
\text { believes differentiates her from women who have derailed. }\end{array}$ \\
\hline 3 & $\begin{array}{l}\text { Emotional awareness and } \\
\text { control }\end{array}$ & $\begin{array}{l}\text { Participant } 3 \text { described the high emotionality of derailed women leaders, but holds the belief that } \\
\text { appropriate emotion in the workplace, especially when linked to organisational initiatives which } \\
\text { have a potential negative impact on others, is acceptable. } \\
\text { She further shared that her ability to emotionally detach, when required. }\end{array}$ \\
\hline
\end{tabular}




\begin{tabular}{|c|c|c|}
\hline 4 & Cultivating networks & $\begin{array}{l}\text { This participant shared a number of examples where her ability to make use of her networks has } \\
\text { helped her meet difficult organisational challenges. } \\
\text { She also shared that this is something she has had to teach herself as few women tend to } \\
\text { focus on building their networks. }\end{array}$ \\
\hline 5 & Resilience & $\begin{array}{l}\text { P3 shared her experience of her father committing suicide when she was } 18 \text { years old and how } \\
\text { this impacted on her sense of identity. Having been very close to her father, she regards his } \\
\text { suicide as being the single biggest life changing event which she has faced, forcing her to review } \\
\text { her sense of self and her view of the world. She shared that her struggle to come to terms with } \\
\text { his death has equipped her to cope with her challenges as a leader and has armed her with a } \\
\text { sense of belief in her to cope with any challenge. }\end{array}$ \\
\hline 6 & $\begin{array}{l}\text { Self-Discipline to balance } \\
\text { multiple roles and } \\
\text { demands }\end{array}$ & $\begin{array}{l}\text { This participant shared the challenges she experienced in managing all the roles which she is } \\
\text { required to fulfil. Her success in doing so was due to having the self-discipline to use her } \\
\text { limited time constructively, making sacrifice and managing time (e.g. not going to all school } \\
\text { functions, waking up extremely early), and boundaries (learning to say no). }\end{array}$ \\
\hline 7 & $\begin{array}{l}\text { Analysing, interpreting and } \\
\text { responding to behaviour of } \\
\text { others }\end{array}$ & $\begin{array}{l}\text { Participant } 3 \text { described the importance of and her ability to garner support though } \\
\text { understanding the behaviour of others. }\end{array}$ \\
\hline 8 & $\begin{array}{l}\text { Achievement drive and } \\
\text { perseverance }\end{array}$ & $\begin{array}{l}\text { She also described her persistence and doggedness. She also referred to the importance of } \\
\text { enduring rather than escaping difficult situations. }\end{array}$ \\
\hline 9 & $\begin{array}{l}\text { Recognition from } \\
\text { significant others }\end{array}$ & $\begin{array}{l}\text { The participant described the importance of recognition from her family and her lack of } \\
\text { expectation from receiving it in the work environment, despite its positive impact. }\end{array}$ \\
\hline 10 & $\begin{array}{l}\text { Confidence to take risks } \\
\text { and be flexible }\end{array}$ & $\begin{array}{l}\text { Participant } 3 \text { described that as a senior leader, she is required to take risks and that she } \\
\text { consciously practices doing so. She links this to confidence, good judgment and flexibility. }\end{array}$ \\
\hline 11 & $\begin{array}{l}\text { Appreciation for gender } \\
\text { differences }\end{array}$ & $\begin{array}{l}\text { She expressed having an appreciation for the world-view and differing contributions of } \\
\text { different genders. This has contributed to her success. }\end{array}$ \\
\hline 12 & Realistic worldview & $\begin{array}{l}\text { P3 appears to have a very realistic view of what she can achieve. In describing this, she did } \\
\text { not appear to experience any negativity or resignation, but merely expressed it as a statement } \\
\text { of fact. She believes that acceptance of this reality has enabled her not to derail. }\end{array}$ \\
\hline
\end{tabular}

\begin{tabular}{|c|c|c|c|}
\hline No & Construct & Description & Supporting quotes \\
\hline \multicolumn{4}{|c|}{ Participant 4} \\
\hline 1 & Self-belief and -confidence & \multicolumn{2}{|c|}{$\begin{array}{l}\text { P4 shared her strong belief in herself and her identity of "being the best". This also implies the } \\
\text { pitfalls of women believing that they are not as good as men. }\end{array}$} \\
\hline 2 & Positive outlook & \multicolumn{2}{|c|}{$\begin{array}{l}\text { The participant shared her belief that derailed women have a sense of unhappiness and } \\
\text { dissatisfaction, whilst she sees herself as being a positive individual. }\end{array}$} \\
\hline 3 & $\begin{array}{l}\text { Aversion to emotional } \\
\text { displays and use of emotion } \\
\text { as a tool }\end{array}$ & \multicolumn{2}{|c|}{$\begin{array}{l}\text { She expressed dislike for either men or women who are "drama queens" and for people who } \\
\text { use their emotions for their own ends. She reports that he inappropriate use of emotions } \\
\text { impacts on one's credibility in that people stop listening. }\end{array}$} \\
\hline 4 & $\begin{array}{l}\text { Taking cognisance of } \\
\text { others opinions and needs }\end{array}$ & \multicolumn{2}{|c|}{ P4 shared the importance of obtaining input and caring for others as a tool for her success. } \\
\hline 5 & Tolerance for stress & & \\
\hline 6 & $\begin{array}{l}\text { Ability to deal with } \\
\text { disappointment/failure and } \\
\text { adversity }\end{array}$ & \multicolumn{2}{|c|}{$\begin{array}{l}\text { She shared some of her disappointments and how her ability to deal with them helped prevent } \\
\text { her from derailing. It could be seen in her sharing of these experiences, specifically with regards } \\
\text { to her studies, that these had affected her deeply, at the time. }\end{array}$} \\
\hline 7 & $\begin{array}{l}\text { Balancing } \\
\text { and roles }\end{array}$ & \multicolumn{2}{|c|}{$\begin{array}{l}\text { Throughout my interaction with P4, I was overwhelmed by her humility and almost self-effacing } \\
\text { approach, despite her underlying air of confidence and success. She attributes this to not taking } \\
\text { herself too seriously and taking time to step away from her role of CEO at times. }\end{array}$} \\
\hline 8 & Realistic self-image & \multicolumn{2}{|c|}{ This participant showed a willingness to introspect and be honest about her flaws. } \\
\hline
\end{tabular}




\begin{tabular}{|l|l|l|}
\hline 9 & Drive for success & $\begin{array}{l}\text { P4 expressed her sense of tenacity, drive, perseverance, competitiveness and need to win.She } \\
\text { also shared the importance of being goal- and results-orientated }\end{array}$ \\
\hline 10 & Need for recognition & $\begin{array}{l}\text { Participant 4 provided a useful insight about using her need for recognition to drive her } \\
\text { success." }\end{array}$ \\
\hline 11 & $\begin{array}{l}\text { Risk taking and openness } \\
\text { to change }\end{array}$ & $\begin{array}{l}\text { She expressed the importance of taking risks, seizing opportunities and not being rigid in } \\
\text { one's expectations. }\end{array}$ \\
\hline 12 & $\begin{array}{l}\text { Mature and pragmatic } \\
\text { approach to gender } \\
\text { inequities }\end{array}$ & $\begin{array}{l}\text { The participant shared her view on the gender inequities which exist. She appears to have a } \\
\text { mature and pragmatic approach to these. }\end{array}$ \\
\hline 13 & Accepting compromise & $\begin{array}{l}\text { Participant 4 displayed a realistic acknowledgment of compromises and decisions which she } \\
\text { had to make in her career. }\end{array}$ \\
\hline
\end{tabular}

\begin{tabular}{|c|c|c|}
\hline No & Construct & Supporting quotes \\
\hline \multicolumn{3}{|c|}{ Participant 5} \\
\hline 1 & Self-belief & $\begin{array}{l}\text { She shared her perception of women who do not have sufficient self-belief and how this can } \\
\text { derail them. }\end{array}$ \\
\hline 2 & $\begin{array}{l}\text { Seeking positive meaning } \\
\text { in events }\end{array}$ & $\begin{array}{l}\text { This participant shared her belief in a positive future and finding meaning in the events that } \\
\text { occur. }\end{array}$ \\
\hline 3 & Emotional control & $\begin{array}{l}\text { P5 shared her ability to put her emotions aside and display an ability to deal with situations } \\
\text { calmly and in a stable manner. }\end{array}$ \\
\hline 4 & Trusting relationships & $\begin{array}{l}\text { The participant displayed an innate belief in the good in human nature. She also expressed the } \\
\text { ability to build deeper and trusting relationships with colleagues, whilst being able to maintain a } \\
\text { professional relationship with them. }\end{array}$ \\
\hline 5 & $\begin{array}{l}\text { Sponsorships in the } \\
\text { workplace }\end{array}$ & $\begin{array}{l}\text { She described being able to identify people in the organisation who she trust and who trust } \\
\text { her and with whom to test her opinions with. She described being able to become emotional } \\
\text { with these sponsors, but then afterwards being better able to deal with things. }\end{array}$ \\
\hline 6 & $\begin{array}{l}\text { Resilience and dealing with } \\
\text { adversity }\end{array}$ & She described her emotional resilience and ability to learn from past mistakes. \\
\hline 7 & $\begin{array}{l}\text { Balancing multiple roles } \\
\text { and demands }\end{array}$ & $\begin{array}{l}\text { The participant expressed the psychological and mental strength required to deal with the } \\
\text { challenges of multiple roles without allowing it to derail her career. }\end{array}$ \\
\hline 8 & $\begin{array}{l}\text { Self-insight and self- } \\
\text { awareness }\end{array}$ & $\begin{array}{l}\text { She expressed having insight into herself, but also displayed insight into the behaviour of } \\
\text { others. }\end{array}$ \\
\hline 9 & $\begin{array}{l}\text { Passion and drive to } \\
\text { succeed }\end{array}$ & $\begin{array}{l}\text { P5 spoke with passion about her pro-active, almost obsessive engagement with the world } \\
\text { around her. She expressed that this has helped her succeed in her career, where others have } \\
\text { been unable to. } \\
\text { She also specifically highlighted the role of perseverance in her success. }\end{array}$ \\
\hline 10 & $\begin{array}{l}\text { Sincere and genuine } \\
\text { recognition for } \\
\text { achievements }\end{array}$ & $\begin{array}{l}\text { The participant shared that because recognition is a part of the organisational culture, it can } \\
\text { sometimes come across as "institutionalised" and that this has the opposite effect to recognition } \\
\text { which is experienced as sincere and genuine. }\end{array}$ \\
\hline 11 & $\begin{array}{l}\text { Flexibility and open- } \\
\text { mindedness }\end{array}$ & $\begin{array}{l}\text { She expressed her enjoyment in having opportunities to experiment with new undertakings and } \\
\text { improvements, despite the discomfort it causes. She highlighted the importance of flexibility, and } \\
\text { how it contributed to her success. }\end{array}$ \\
\hline 12 & $\begin{array}{l}\text { Realistic approach and } \\
\text { compromise }\end{array}$ & $\begin{array}{l}\text { P5 expressed the importance of the need to compromise and of being realistic within the } \\
\text { context of being a woman leader. }\end{array}$ \\
\hline 13 & $\begin{array}{l}\text { Dealing with gender } \\
\text { differences }\end{array}$ & $\begin{array}{l}\text { The Participant acknowledged that differences in gender exist, especially in terms of } \\
\text { credibility being assigned based on gender. She further described how she deals with it. }\end{array}$ \\
\hline
\end{tabular}

\section{Discussion and findings}

Based on the experiences of derailment and the definitions of derailment provided by the participants in this study, we were able to arrive at a more inclusive definition of leadership derailment. This definition is as follows:

when an individual in an executive role who was judged to have the ability to be successful in a role, lacks specific personal characteristics, and thus unexpectedly: 
- opts out of the position,

- is fired,

- is asked to resign,

- is forced out of the organization,

- $\quad$ has their career plateau below the levels of achievement expected by themselves and others,

- is undermined because of a specific role they are forced to play,

- $\quad$ is unable to effectively overcome or deal with issues of gender discrimination or other inequities.

- $\quad$ is unable to balance multiple roles required, due to lack of support structures

and then fails to take responsibility for failure in the role by blaming external factors, in the event of it being of their own doing.

In addition to the above, an exploration of the constructions of the participants yielded 11 themes, which emerged from the data. Research findings show that it is the existence of a particular personal construct system, which impacts on behaviour and thus characteristics possessed by women leaders, which can prevent their derailment.

Findings further show that it is the combination of a set of personal and core constructs, rather than a particular personal or core construct or group of personal or core construct, which manifest in the characteristics which prevent derailment. These personal and core constructs are as follows:

\section{Table 7: Core and personal constructs preventing derailment}

\begin{tabular}{|ll|c|l|}
\hline Construct & Frequency & Theme \\
\hline P1 & Self-confidence & 5 & Self-confidence and delf-efficacy \\
P2 & "I'm okay" & & \\
P3 & Confidence in abilities and ability to assert self & & \\
P4 & Self-belief and -confidence & & \\
P5 & Self-belief & 5 & Positive outlook/optimism \\
\hline P1 & Positivity & & \\
P2 & Positive Thinking & & \\
P3 & Positive and calm approach. & & \\
P4 & Positive Outlook & 5 & Emotional maturity and managing \\
P5 & Seeking positive meaning in events & & emotions \\
\hline P1 & Emotional awareness & & \\
P2 & Emotional control and self-awareness & & \\
P3 & Emotional awareness and control & 7 & Building \\
P4 & Aversion to emotional displays and use of emotion as a tool & & networks \\
P5 & Emotional control & & \\
\hline P1 & Team work & & \\
P1 & Relationship focus & & \\
P2 & Nurturing relationships and the needs of others & & \\
P3 & Cultivating networks & & \\
P4 & Taking cognisance of others opinions and needs & & \\
P5 & Trusting relationships & & \\
P5 & Sponsorships in the workplace & & \\
\hline P5 & Resilience and Coping Mechanisms & & \\
P1 & & & \\
P2 & Stress management and dealing with adversity & & \\
P3 & Resilience & & \\
P4 & Tolerance for stress & & \\
P4 & Ability to deal with disappointment/failure and adversity & & \\
P5 & Dealing with adversity & & \\
\hline P1 & Work-life balance & & \\
P2 & Managing demands of multiple roles & & \\
P5 & Balancing Multiple Roles and Demands & & \\
P3 & Self-discipline to balance Multiple Roles and Demands & & \\
& & & \\
\end{tabular}




\begin{tabular}{|c|c|c|c|}
\hline P4 & Balancing responsibilities and roles & & \\
\hline P1 & Responsiveness to own and other's behaviours & \multirow[t]{5}{*}{5} & \multirow[t]{5}{*}{ Insight into behaviour } \\
\hline $\mathrm{P} 2$ & Understanding behaviour and dealing with conflict & & \\
\hline P3 & Analysing, interpreting and responding to behaviour of others & & \\
\hline P4 & Realistic self-image & & \\
\hline P5 & Self-insight and self-awareness & & \\
\hline P1 & Passion and drive & \multirow[t]{5}{*}{5} & \multirow{5}{*}{$\begin{array}{lll}\text { Achievement } & \text { drive } & \text { and } \\
\text { perseverance } & & \\
\end{array}$} \\
\hline $\mathrm{P} 2$ & Success driven & & \\
\hline P3 & Achievement Drive and Perseverance & & \\
\hline P4 & Drive for success & & \\
\hline P5 & Passion and drive to succeed & & \\
\hline P1 & $\begin{array}{l}\text { Recognition for and Reinforcement from others for } \\
\text { contributions }\end{array}$ & \multirow[t]{5}{*}{5} & \multirow[t]{5}{*}{ Recognition from significant others } \\
\hline $\mathrm{P} 2$ & Accepting and giving recognition for achievements & & \\
\hline P3 & Recognition from significant others & & \\
\hline P4 & Need for Recognition & & \\
\hline P5 & Sincere and genuine recognition for achievements & & \\
\hline P1 & Risk taking and following one's instincts & \multirow[t]{5}{*}{5} & \multirow{5}{*}{$\begin{array}{l}\text { Risk taking and openness to } \\
\text { change }\end{array}$} \\
\hline P2 & Confidence to take risks & & \\
\hline P3 & Confidence to take risks and be flexible & & \\
\hline P4 & Risk Taking and Openness to Change & & \\
\hline P5 & Flexibility and open-mindedness & & \\
\hline P3 & Realistic worldview & \multirow[t]{9}{*}{8} & \multirow{9}{*}{$\begin{array}{l}\text { Pragmatic approach to gender } \\
\text { issues and willingness to } \\
\text { compromise }\end{array}$} \\
\hline P4 & Accepting compromise & & \\
\hline P5 & Realistic approach and compromise & & \\
\hline P1 & Understanding and capitalising on gendered behaviour & & \\
\hline $\mathrm{P} 2$ & Dealing with gender inequality & & \\
\hline P3 & Appreciation for gender differences & & \\
\hline P4 & Mature and pragmatic approach to gender inequities & & \\
\hline P5 & Dealing with gender differences & & \\
\hline $\mathrm{P} 2$ & Identity as a women as part of leadership identity & & \\
\hline
\end{tabular}

Considering the above analysis and interpretation of the core constructs and personal constructs held by women leaders who have avoided or overcome derailment, a new framework for inclusion in future derailment research is proposed. This framework can be graphically represented as follows:

Figure 1 Characteristics preventing derailment

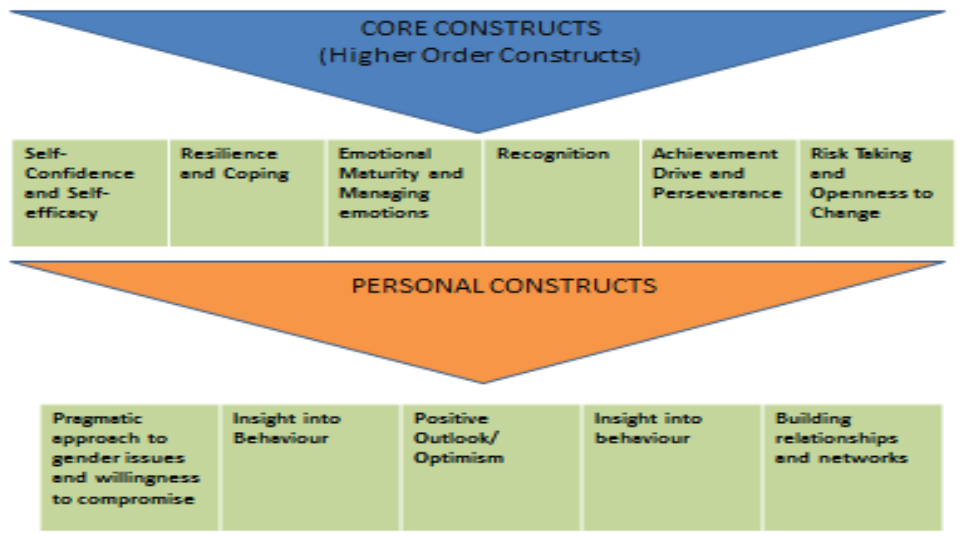


This framework could provide insight into the study of leadership derailment and assist in making women aware of what may cause derailment, prepare them better to deal with it and to develop the characteristics and behaviours required to avoid or overcome derailment. It is my belief that this will contribute greatly to the worldwide gender parity and transformation agenda at senior organisational levels.

\section{Conclusion}

In conclusion, this article attempts to explore the characteristics that prevent the derailment of women leaders based on their personal construct systems and to present an integrated framework of these characteristics. A secondary aim of this article is to provide a more inclusive definition of leadership derailment.

Based on the findings of this study, it appears that the characteristics which prevent derailment develop as a result of useful and supportive personal and core constructs which women leaders hold. By better understanding these personal and core constructs, CEOs and human resources practitioners may be in a better position to recruit, select and place women executives who are less likely to derail. In addition, policy makers and drivers of organisational change may be empowered to put in place support mechanisms, training and developmental initiatives as well as coaching and mentoring practices that reliably decrease the number of executive women leaders in their businesses who derail.

The personal and core constructs which women leaders hold have the power to influence their behaviour in a relatively consistent manner. Gaining insight into and exploring the constructs of women leaders who have not fallen prey to derailment, can make a contribution to our understanding of leadership derailment amongst women leaders. This can empower women leaders through the investigation of alternative constructions, which may lead to growth, reaching of new insights, learning of new behaviours, and ultimately increased success within the leadership realm.

\section{References}

Amaratunga, D., Baldry, D., Sarshar, M., \& Newton, R. (2001). Quantitative and qualitative research in the built environment: application of "mixed" research approach. International Journal of Productivity and Performance Management, 51(1), 17-31. doi: $10.1108 / 00438020210415488$.

Bentz, V. J. (1967). The Sears experience in the investigation, description and prediction of executive behaviour. In F. R. Wickert, \& D. E. McFarland (Eds.), Measuring executive effectiveness, 147-206. New York: Appleton-Century Crofts.

Bentz, V. J. (1985a) Research findings from personality assessment of executives. In J. H. Bernardin, \& D. A. Bownas (Eds.), Personality assessment in organizations, 82-144. New York: Praeger Publishers.

Bentz, V. J. (1985a, August). A view from the top: A thirty-year perspective on research devoted to discovery, description, and prediction of executive behaviour. Paper presented at the 93rd Annual Convention of the American Psychological Association, Los Angeles.

Bentz, V. L. (1985b). Research findings from personality assessment of executives. In J. H. Bernardin \& D. A. Bownas (Eds.), Personality assessment in organization (pp. 82-144). New York: Praeger.

Bentz, V. J. (1990). Contextual issues in predicting high-level leadership performance. In K. E. Clark \& M. B. Clark (Eds.), Measures of leadership, 131-144. West Orange, NJ: Leadership Library of America.

Bogdan, R. \& Biklen, S. K. (2007). Qualitative research for education. An introduction to theory and methods, $4^{\text {th }}$ ed. Allyn \& Bacon/Pearson Education Group.

Butler, R. J. (2006). Personal Construct Theory \& Practice: Investigating the Content of Core Constructs (3rd ed.). United Kingdom: Lea House, Leeds.

Catalyst (2005). Women "take care", men "take charge:" Stereotyping of U.S.

Commission for employment equity annual report 2011-2012 (2012). Department of Labour, Republic of South Africa.

Creswell, J. W. (1998). Qualitative inquiry and research design. Choosing among five traditions. Thousand Oaks, CA: Sage.

Denzin, N. K., \& Lincoln, Y. S. (2008). Strategies of Qualitative Inquiry (3rd ed.). United States of America: Sage Publications.

Dotlitch, D. L., \& Cairo, P. (2003). Why CEOs Fail: The 11 Behaviours That Can Derail Your Climb to the Top and How to Manage Them, San Francisco, CA: Jossey-Bass.

Eagly, A. H., \& Johnson, B. T. (1990). Gender and leadership style: A meta-analysis. Psychological Bulletin, 108, $233-256$.

Eagly \& Makhijani, 1992; Heilman et al., 2004; Ruderman \& Ohlott, 2002, Valian, 2000). Zenger and Folkman (2002) Leslie \& Van Velsor, (1996), (pp. 17).

Eichinger, R. W., \& Lombardo, M. M. (2003). Knowledge summary series: 360-degree assessment. Human Resources Planning, 26, 3444.

Eisenhart, J. M. (2006). The meaning and use of power among female corporate leaders. Unpublished doctoral dissertation. Santa Barbara, CA: Fielding Graduate University.

Epting, F. R., \& Paris, M. E. (2006). A Constructive Understanding of the Person: George Kelly and Humanistic Psychology. The Humanistic Psychologist, 34(1), 21-37.

Finkelstein, S. M. (2003). Why smart executives fail: And what we can learn from their mistakes. New York, NY: Portfolio. 
Fiske, S. T., Bersoff, D. N., Borgida, E., Deaux, K., \& Heilman, M. E. (1991). Social science research on trial. American Psychologist, 46, 1049-1060

Furnham, A. (2010). The Elephant in the Boardroom: The Causes of Leadership Derailment. London: Palgrave Macmillan.

Gilmore, A. \& Carson, D. (1996). Integrative qualitative methods in a services context. Marketing Intelligence \& Planning. 14(6), 42 51.

Heilman, M. E., Wallen, A. S., Fuchs, D., \& Tamkins, M. M. (2004). Penalties for success: Reactions to women who succeed at male gender-typed tasks. Journal of Applied Psychology, 89, 416-427.

Hogan, R., \& Hogan, J. (2001). Assessing leadership: a view of the dark side. International Journal of Evaluation and Assessment, 9 , 40-51.

Kellerman, Barbara (2004). Bad Leadership. Boston, Massachusetts: Harvard Business School Press.

Kelly, G. (1955). The Psychology of Personal Constructs, vols. 1 and 2. New York: Norton.

Leitner, L., \& Thomas, J. (2003). Experiential personal construct psychotherapy. In F. Fransella (Ed.), International Handbook of Personal Construct Psychology. Chichester: John Wiley \& Sons.

Lofland, J. \& Lofland, L.H. (1984). Analysing social settings: a guide to qualitative observations and analysis (2nd ed.). Belmont: Wadsworth.

Lombardo, M. M., Ruderman, M. N., \& McCauley, C. D. (1988). Explanations of Success and Derailment in Upper-Level Management Positions. Journal of Business and Psychology, 2(3), 199-216.

Lord Davies Report. (2013, April). Women on Boards. Retrieved from https://www.gov.uk/government/uploads/system/uploads lattachment data/file/182602/bis-13-p135-women-on-boards-2013.pdf.

Mason, J. (1996). Qualitative researching. CA: Sage.

McCall, M. W. Jr., \& Lombardo, M. M. (1983). Off the track: Why and how successful executives get derailed. Technical Report No. 21. Greensboro, NC: Centre for Creative Leadership.

McCoy, M. M. (1977). A reconstruction of emotion. In D. Bannister (Ed.), New Perspectives in Personal Construct Theory. London: Academic Press.

Meyerson, D. E., \& Fletcher, J. K. (2000, January - February). A modest manifesto for shattering the glass ceiling. (Reprint R00107). Harvard Business Review.

Morrison, A. M., White, R. P., \& Van Velsor, E (1987). Breaking the glass ceiling. Reading, MA: Addison-Wesley.

Morrison, A., White, R., Van Velsor, E., \& Centre for Creative Leadership. (1992). Breaking the Glass Ceiling: Can women reach the top of Americas largest corporations? (2nd ed.). Reading, MA: Addison-Wesley.

Powell, G. N., Butterfield, A. D., \& Parent, J. D. (2002). Gender and managerial stereotypes: Have the times changed? Journal of Management, 28, 177-193.

Powell, G. N., \& Graves, L. M. (2003). Women and men in management (3rd ed.). Thousand Oaks, CA: Sage.

Rasch, R., Shen, W., Davies, S. E., \& Bono, J. (2008, April). The development of a taxonomy of ineffective leadership behaviours. Paper presented at the $23^{\text {rd }}$ Annual Conference of the Society for Industrial and Organizational Psychology, San Francisco, CA.

Rowe, D. (2003). Personal construct psychology and me. In F. Fransella (Ed.), International Handbook of Personal Construct Psychology. Chichester: John Wiley \& Sons.

Schein, V. E. (1973). The relationship between sex role stereotypes and requisite management characteristics. Journal of Applied Psychology, 57, 95-100.

Schein, V. E. (1975). The relationship between sex role stereotypes and requisite management characteristics among female managers. Journal of Applied Psychology, 60, 340 - 344

Schein, V. E., \& Mueller, R. (1992). "Sex role stereotyping and requisite management characteristics: a cross-cultural look". Journal of Organizational Behavior, 13, 439-47.

Schein, V. E. (2007). Woman in management: reflections and projections. Women in Management Review, 22(1), 6-18.

Schmidt, L. M. (2009). Executive Women's Perceptions of their Career Derailment. United States: Fielding Graduate University.

Schneider, D. J. (2004). The psychology of stereotyping. New York: Guilford.

Schram, T. H. (2006). Conceptualizing and proposing qualitative research (2nd ed.). Upper Saddle River, NJ: Pearson Education Inc.

Schwandt, T. A. (2007). The dictionary of qualitative research (3rd ed.). Thousand Oaks, CA: Sage.

Strauss, A. \& Corbin, J. (1990). Basics of qualitative research: grounded theory procedures and techniques. London: Sage Publications. Valian, V. (2000). Why so slow? The advancement of women. Cambridge, MA: First MIT Press.

Van Velsor, E., \& Leslie, J. B. (1995). Why executives derail: perspectives across time and cultures. Academy of Management Review, 9, 62-72. 
E-ISSN 2039-2117

ISSN 2039-9340
Mediterranean Journal of Social Sciences MCSER Publishing, Rome-Italy
Vol 5 No 2 January 2014 